\title{
PENGARUH MODEL PEMBELAJARAN COMPLETE SENTENCE TERHADAP HASIL BELAJAR SISWA
}

\author{
Elin Fitriani ${ }^{1}$, Rustopo $^{2}$, Mei Fita Asri Untari ${ }^{3}$ \\ ${ }^{1,2,3}$ Pendidikan Guru Sekolah Dasar, Fakultas IImu Pendidikan,Universitas PGRI Semarang \\ Email : elin_14fitriani@yahoo.com ${ }^{1}$
}

\begin{abstract}
Abstrak
Latar belakang yang mendasari penelitian ini adalah rendahnya hasil belajar siswa pada mata pelajaran tematik khususnya Tema Pahlawanku Subtema Pahlawan Kebanggaanku. Jenis penelitian ini adalah kuantitatif. Desain yang digunakan adalah One-Group PretestPostest Design. Populasi dalam penelitian ini yakni seluruh siswa kelas IV SD N Tlgomulyo. Jumlah sampel dalam penelitian ini yakni 41 siswa. Teknik pengumpulan data meliputi tes dan non tes. Tes terdiri dari beberapa soal yang harus dikerjakan siswa. Adapun dalam model ini, siswa mengerjakan soal dengan cara melengkapi bagian rumpang yang terdapat dalam bacaan. Tes ini merupakan instrumen yang terlebih dahulu diuji validitas, reliabilitas, daya beda dan taraf kesukaran. Sedangkan non tes terdiri dari observasi, dokumentasi, dan wawancara. Penelitian ini menggunakan uji prasyarat normalitas data awal yang diambil dari pretest, normalitas akhir yang diambil dari posttest, uji t dan uji ketuntasan. Berdasarkan hasil penelitian, dalam uji $t$ diperoleh $t_{\text {hitung }}(22,804)$ dan $t_{\text {tabel }}(1,684)$. dapat disimpulkan bahwa $\mathrm{t}_{\text {hitung }}>\mathrm{t}_{\text {tabel }}$. Hal ini menunjukkan bahwa model pembelajaran complete sentence berbantu media video berpengaruh terhadap hasil belajar tema Pahlawanku Subtema Pahlawan Kebangganku kelas IV SD N Tlogomulyo.
\end{abstract}

Kata kunci : model pembelajaran complete sentence, hasil belajar

\begin{abstract}
The background that underlies this research is the low student learning outcomes in thematic subjects, especially the theme of my hero My Pride Heroes Subtema. This type of research is quantitative. The design used is the One-Group Pretest-Postest Design. The population in this study were all fourth grade students of SD N Tlgomulyo. The number of samples in this study were 41 students. Data collection techniques include tests and non-tests. The test consists of several questions students must do. As for this model, students work on the problem by completing the passages in the reading. This test is an instrument that is first tested for validity, reliability, power difference and degree of difficulty. Whereas non tests consist of observation, documentation, and interviews. This study uses the prerequisite test for the normality of the initial data taken from the pretest, final normality taken from the posttest, $t$ test and completeness test. Based on the results of the study, in the test obtained t_count (22.804) and t_table (1.684). it can be concluded that $t$ count $>t$ table. This shows that the complete sentence learning model is assisted by video media influencing the learning outcomes of my Heroes' Pride Subtema class IV theme at SD N Tlogomulyo.
\end{abstract}

Keywords: complete sentence learning model, learning outcomes 


\section{Pendahuluan}

Pendidikan adalah suatu upaya penting dimana melalui pendidikan manusia dapat meningkatkan kualitas hidup. Kualitas pendidikan dapat dilihat dari kualitas pembelajaran. Menurut Undang-Undang Sistem Pendidikan Nasional No. 20 Tahun 2003 mengemukakan bahwa: "Pendidikan adalah usaha sadar dan terencana untuk mewujudkan suasana belajar dan proses pembelajaran agar peserta didik secara aktif mengembangkan potensi dirinya untuk memiliki kekuatan spriritual keagamaan, pengendali diri, kepribadian, kecerdasan, akhlak mulia, serta keterampilan yang diperlukan dirinya, masyarakat, bangsa dan negara."

Pendidikan terbagi menjadi tiga jenjang yaitu pendidikan dasar, menengah dan tinggi. Pendidikan seharusnya dilaksanakan dengan berdasar kepada tujuan pedidikan yang telah ditetapkan yaitu yang tercantum dalam Undang-Undang Sistem Pendidikan Nasional No. 20 Tahun 2003 yaitu mengembangkan kemampuan dan membentuk watak serta peradaban bangsa yang bermartabat dalam rangka mencerdaskan kehidupan bangsa, bertujuan untuk berkembangnya potensi peserta didik agar menjadi manusia yang beriman dan bertakwa kepada Tuhan Yang Maha Esa, berakhlak mulia, sehat, berilmu, cakap, kreatif, mandiri, dan menjadi warga negara yang demokratis serta bertanggung jawab.

Joyce dan Weill (Huda, 2013 : 73) model pembelajaran adalah rencana atau pola yang dapat digunakan untuk membentuk kurikulum, mendesain materi-materi instruksional, dan memandu proses pengajaran di ruang kelas atau di setting yang berbeda. Model pembelajaran complete sentence merupakan salah satu pembelajaran yang berusaha mempertimbangkan kemampuan siswa untuk memprediksi fragmen-fragmen teks yang ditugaskan pada mereka (Huda, 2013:313). Model pembelajaran kooperatif Complete Sentence merupakan model pembelajaran yang dapat digunakan untuk meningkatkan perhatian siswa dalam proses pembelajaran. Model pembelajaran ini merangsang perhatian siswa untuk mengikuti proses pembelajaran dan siswa dapat menghafal materi pembelajaran dengan melengkapi paragraph yang masih kosong yang disediakan guru yang sesuai dengan materi yang sudah disampaikan guru (Agustini dkk, 2017 : 3). Dengan adanya model pembelajaran, diharapkan tujuan pembelajaran dapat tercapai sebagaimana yang telah ditetapkan. Selain model pembelajaran, diperlukan media sebagai alat bantu yang dapat mendukung kegiatan pembelajaran sehingga diharapkan siswa dapat tertarik dalam pembelajaran.

Sanjaya (Ainina, 2014:41) media pembelajaran adalah seluruh alat dan bahan yang dapat dipakai untuk tujuan pendidikan seperti radio, televisi, buku, koran, majalah, komputer dan lain sebagainya. Selain alat-alat tersebut orang dan bahan serta peralatan yang menciptakan kondisi yang memungkinkan siswa memperoleh pengetahuan, kterampilan dan sikap juga disebut sebagai media pembelajaran. Asra (Setiawan, 2013) mengungkapkan bahwa media audio visual adalah salah satu media yang dapat dilihat dan didengar, seperti film bersuara, video, TV, dan sound slide. Dengan adanya media, diharapkan siswa dapat menerima materi dengan baik karena telah disajikan contoh konkrit. Media pembelajaran hendaknya dapat memuat semua cakupan materi baik untuk kurikulum tingkat satuan pendidikan (KTSP) maupun kurikulum 2013 yang menggunakan sistem tematik.

Trianto (Solekhah, 2014) pembelajaran tematik pada dasarnya adalah model pembelajaran terpadu yang menggunakan tema untuk mengaitkan beberapa mata pelajaran sehingga dapat memberikan pengalaman bermakna kepada siswa. Dengan adanya pembaharuan kurikulum, diharapkan dapat diharapkan semua pihak dapat melaksanakannya dengan baik sehingga dapat meningkatkan hasil belajar siswa. Sudijono (Sutrisno dan Siswanto, 2016:114) mengungkapkan hasil belajar merupakan sebuah tindakan evaluasi yang dapat mengungkap aspek proses berpikir (cognitive domain) juga dapat mengungkap aspek kejiwaan lainnya, yaitu aspek nilai atau sikap (affective domain) dan aspek keterampilan (psychomotor domain) yang melekat pada diri setiap individu peserta didik. 
Shoimin (2017:35-37) pembelajaran complete sentence adalah model pembelajaran menggunakan kunci jawaban yang tersedia. Suprijono dan Agus (Widyawati, 2016) model pembelajaran complete sentence menggunakan media blangko isian berupa paragraf yang kalimatnya belum lengkap. Berbeda pendapat dengan Andayani (Wantini, 2017:258) menuturkan model complete sentence merupakan rangkaian proses pembelajaran yang diawali dengan menyampaikan materi ajar oleh guru, atau dengan penganalisaan terhadap modul yang telah dipersiapkan, pembagian kelompok yang tidak lebih dari tiga orang dengan kemampuan yang heterogen, pemberian lembar kerja yang berisi paragraf yang belum lengkap, lalu diberikan kesempatan kepada siswa untuk berdiskusi dan diakhiri dengan pengambilan kesimpulan. Berdasarkan paparan di atas dapat ditarik kesimpulan bahwa model pembelajaran complete sentence adalah model pembelajaran yang dapat digunakan sebagai alternatif dalam pelaksanaan pembelajaran dimana siswa melengkapi suatu paragraf yang rumpang dengan jawaban-jawaban yang telah tersedia.

Huda (2013:313) menjelaskan bahwa complete sentence memiliki serangkaian proses pembelajaran yang diawali dengan penyampaian materi ajar oleh guru, analisis terhadap modul yang telah dipersiapkan, pembagian kelompok yang tidak boleh lebih dari tiga orang dengan kemampuan yang heterogen, pemberian lembar kerja yang berisi paragraf yang belum lengkap, lalu pemberian kesempatan kepada siswa untuk berdiskusi dan diakhiri dengan pengambilan kesimpulan. Berdasarkan paparan di atas dapat disimpulkan bahwa komponen penting dalam pembelajaran ini adalah modul, pembentukan kelompok secara heterogen maksimal tiga orang dan pengambilan keputusan.

Shoimin (2017) menjelaskan bahwa model complete sentence memiliki beberapa kelebihan yaitu : (i) mudah dibuat guru karena hanya menghilangkan satu kata untuk dibuat kalimat; (ii) siswa tidak perlu menjelaskan jawabannya dan hanya memadukan kata-kata yang sesuai dengan kalimat; (iii) siswa diajarkan untuk mengerti dan hafal mengenai materi.

Shoimin menjelaskan bahwa model complete sentence memiliki kekurangan yaitu : (i) guru kurang kreatif dan inovatif dalam membuat soal; (ii) siswa kurang terpacu mencari jawaban karena hanya cukup menebak kata; (iii) kurang cocok digunakan untuk semua bidang studi. Berdasarkan paparan di atas dapat disimpulkan bahwa setiap model memiliki kelebihan dan kekurangannya masing-masing. Untuk itu kita sebagai pendidik harus memaksimalkan kegiatan belajar mengajar dan mengupayakan untuk meminimalisir kekurangan dari model yang kita pilih dengan mengembangkan inovasi-inovasi baru namun tetap berpegang pada prinsip-prinsip model pembelajaran complete sentence seperti yang dikemukakan oleh Shoimin (2017) yaitu : (i) soal yang disampaikan berupa kalimat yang belum lengkap sehingga makna atau arti kalimat tersebut belum dapat dimengerti; (ii) kalimat yang banyak dan saling berkaitan dalam sebuah paragraf dan belum sempurna serta belum dimengerti maknanya; (iii) kalimat dapat dilengkapi dengan pilihan kata yang disediakan; (iv) harus diisi dengan kata-kata tertentu, misal istilah atau kata asing; (v) jawaban dari kalimat yang belum lengkap itu sudah disediakan.

Akbar (2013:69-70) pembelajaran tematik adalah sistem pembelajaran yang memungkinkan siswa baik secara individual atau kelompok aktif mencari, menggali dan menemukan konsep atau prinsip keilmuan secara holistik, bermakna, dan otentik melalui tema tertentu. Pembelajaran tematik merupakan usaha mengintegrasikan pengetahuan, keteampilan, nilai dan sikap, dan pemikiran kreatif dalam pembelajaran dengan meggunakan tema sebagai pokok kajian. Berbeda dengan Trianto (Solekhah, 2014) pembelajaran tematik pada dasarnya adalah model pembelajaran terpadu yang menggunakan tema untuk mengaitkan beberapa mata pelajaran sehingga dapat memberikan pengalaman bermakna kepada siswa.

Berdasarkan paparan di atas, dapat disimpulkan bahwa pembelajaran tematik adalah pembelajaran yang mengintegrasikan beberapa mata pelajaran menjadi satu pembelajaran yang terikat oleh tema. 
Majid (2014:89) menjelaskan beberapa prinsip yang berkenaan dengan pembelajaran tematik integratif yaitu : a.Pembelajaran tematik integratif memiliki satu tema yang aktual, dekat dengan dunia siswa dan ada dalam kehidupan sehari-hari. Tema ini menjadi alat pemersatu materi yang beragam dari beberapa mata pelajaran. B. Pembelajaran tematik integratif perlu memilih materi beberapa mata pelajaran yang mungkin saling terkait. Dengan demikian, materimateri yang dipilih dapat mengungkapkan tema secara bermakna. C. Pembelajaran tematik integratif tidak boleh bertentangan dengan tujuan kurikulum yang berlaku tetapi sebaliknya pembelajaran tematik integratif harus mendukung pencapaian tujuan utuh kegiatan pembelajaran yang termuat dalam kurikulum. D. Materi pembelajaran yang dapat dipadukan dalam satu tema selalu mempertimbangkan karakteristik siswa seperti minat, kemmapuan, kebutuhan dan pengetahuan awal. E. Materi pelajaran yang dipadukan tidak terlalu dipaksakan. Artinya, materi yang tidak mungkin dipadukan tidak usah dipadukan.

Berdasarkan observasi yang dilakukan pada bulan September, dapat disimpulkan bahwa karakteristik siswa berbeda-beda satu dengan yang lain. Fakta membuktikan bahwa siswa kelas IV SD N Tlogomulyo rata-rata siswa senang belajar secara langsung dengan menggunakan media, senang bekerja kelompok dan senang bercerita. Berdasarkan wawancara yang dilakukan pada bulan September dengan narasumber Guru Kelas IV, diketahui bahwa KKM Mata Pelajaran Tematik Tema Pahlawanku SD N Tlogomulyo adalah 69. Namun pada kenyataannya masih banyak siswa yang belum mencapai ketuntasan yang telah ditetapkan. Hal ini dikarenakan siswa belum memiliki ketertarikan untuk membaca buku, penggunaan model pembelajaran yang belum sesuai dengan karakteristik siswa sehingga tujuan pembelajaran belum tercapai serta penggunaan media yang kurang mendukung.

\section{Metode}

Penelitian ini merupakan penelitian eksperimen jenis kuantitatif. Penelitian ini menggunakan One Group Pretest-Posttest Design. Penelitian dilaksanakan di SD N Tlogomulyo Kecamatan Pedurungan Kota Semarang pada tanggal 4-14 Januari 2019.

Populasi dalam penelitian ini adalah semua siswa kelas IV SD N Tlogomulyo Kota Semarang yang berjumlah 41 siswa. Langkah langkah yang digunakan pada penelitian ini adalah dengan melakukan pretest dan posttest. Ketika pretest siswa belum diberi perlakuan kemudian diberi perlakuan berupa model pembelajaran complete sentence berbantu media video dalam beberapa hari dan hari terakhir diberikan posttest. Adanya pretest dan posttest ini digunakan untuk mengetahui perbandingan sebelum dan sesudah diberikan perlakuan.

Penelitian ini menggunakan One Group Pretest-Posttest Design dengan gambaran sebagai berikut :

\begin{tabular}{|lll|}
\hline $\mathrm{O}_{1}$ & $\mathrm{X}$ & $\mathrm{O}_{2}$ \\
\hline
\end{tabular}

Keterangan :

Gambar 1. Desain Penelitian (Sugiyono)

$\mathrm{O}_{1}=$ Nilai Pretest (sebelum diberi perlakuan)

$\mathrm{O}_{2}=$ Nilai Posttest (setelah diberikan perlakuan)

Teknik pengumpulan data yang digunakan dalam penelitian ini adalah metode tes dan non-tes. Tes adalah alat atau prosedur yang digunakan untuk mengetahui atau mengukur sesuatu dalam suasana, dengan cara dan aturan-aturan yang sudah ditentukan. Untuk mengerjakan tes ini tergantung petunjuk yang diberikan misalnya : melingkari salah satu huruf 
di depan pilihan jawaban, menerangkan, mencoret jawaban yang salah, melakukan tugas atau suruhan, menjawab secara lisan dan sebagainya. Tes ini harus diuji tingkat validitas, reliabilitas, indeks kesukaran dan daya beda. Tes digunakan untuk mengukur hasil belajar kognitif. Sedangkan non tes meliputi observasi, wawancara dan dokumentasi. Observasi dilakukan dengan mengamati proses pembelajaran, hal ini bertujuan untuk mengetahui karakteristik siswa ketika pembelajaran sehingga dapat diketahui penyebab dari rendahnya hasil belajar pada tema pahlawanku. Adapaun hasil observasi menunjukkan bahwa siswa belajar dengan menggunakan media. Dokumentasi merupakan suatu cara pengumpulan data dengan menghimpun dan menganalisis dokumen dokumen, baik dokumen tertulis, gambar, maupun elektronik. Dokumentasi dilakukan untuk memperkuat data yang diperoleh melalui observasi. Wawancara digunakan untuk mengumpulkan informasi lebih dalam.

Teknik analisis data peneliti menggunakan uji normalitas, uji homogenitas, uji hipotesis dengan menggunakan uji t dan uji ketuntasan. Uji normalitas digunakan untuk mengetahui kelas tersebut berdistribusi normal atau tidak. Hipotesis dalam penelitian ini adalah :

$\mathrm{H}_{\mathrm{o}}=t_{\text {hitung }}<t_{\text {tabel }}$ artinya :Tidak ada pengaruh model pembelajaran complete sentence terhadap hasil belajar kognitif siswa kelas IV tema pahlawanku SD N Tlogomulyo Semarang. $\mathrm{H}_{\mathrm{a}}=t_{\text {hitung }}>t_{\text {tabel }}$ artinya : Ada pengaruh model pembelajaran complete sentence terhadap hasil belajar kognitif siswa kelas IV tema pahlawanku SD N Tlogomulyo Semarang.

\section{Hasil dan Pembahasan}

Dalam pengaplikasiannya menggunakan teknik prestest dan posttest di kelas yang menjadi tempat penelitian. Prestest dilakukan untuk mengetahui kemampuan awal siswa sebelum menerima perlakuan model pembelajaran complete sentence. Dalam hal ini dapat memanfaatkan media video.. Sedangkan posttest dilakukan untuk mengetahui kemampuan akhir siswa setelah menerima perlakuan model pembelajaran complete sentence. Setelah mendapatkan hasil pretest dan posttest, kemudian dibandingkan. Dari kedua data tersebut apakah ada peningkatan dan sudah mencapai ketuntasan yang telah ditetapkan. Untuk mengetahuinya, bisa menggunakan uji hipotesis dari hasil pretest dan posttest. Dari kedua soal tersebut nantinya akan diketahui bahwa model pembelajaran complete sentence berpengaruh terhadap hasil belajar SD N Tlogomulyo.

Berdasarkan perhitungan data tersebut diperoleh bahwa rata-rata nilai pretestnya adalah 71,80 dengan nilai tertinggi 100 dan terendah 23 sedangkan rata-rata posttestnya adalah 84,80 dengan nilai tertinggi 100 dan terendah 57. Pada pretest total siswa belum mencapai KKM sebanyak 16, sedangkan pada posttest total siswa belum mencapai KKM sebanyak 3 orang. Hal ini mengalami peningkatan ketika sudah diberikan model pembelajaran complete sentence berbantu media video.

Pada uji normalitas awal digunakan untuk mengetahui normal atau tidaknya data awal dari nilai pretest. Data berdistribusi normal apabila Lo < Ltabel. Adapun data tersebut adalah sebagai berikut :

Tabel 1. Uji Normalitas Awal

\begin{tabular}{lc}
\hline & Kelas Eksperimen \\
\hline Lo & 0,083 \\
Ltabel & 0,13837 \\
\hline
\end{tabular}

Sumber : Data Hasil Penelitian (2019) 
Berdasarkan tabel diatas, pada kelas eksperimen diperoleh taraf nyata sebesar 5\% dengan memperoleh Lo $(0,083)<$ Ltabel $(0,13837)$. Jadi, dapat disimpulkan bahwa Ho diterima dan artinya sampel berasal dari populasi berdistribusi normal.

Pada uji normalitas akhir digunakan untuk mengetahui normal atau tidaknya data akhir dari nilai posttest. Data berdistribusi normal apabila Lo < Ltabel. Adapun data tersebut adalah sebagai berikut :

Tabel 2. Uji Normalitas Akhir

\begin{tabular}{lc}
\hline & Kelas Eksperimen \\
\hline Lo & 0,1162 \\
Ltabel & 0,13837 \\
\hline
\end{tabular}

Sumber : Data Hasil Penelitian (2019)

Berdasarkan tabel diatas, pada kelas eksperimen diperoleh taraf nyata sebesar 5\% dengan memperoleh Lo $(0,1162)<$ Ltabel $(0,13837)$. Jadi, dapat disimpulkan bahwa Ho diterima dan artinya sampel berasal dari populasi berdistribusi normal. Hasil perhitungan dapat dilihat pada lampiran.

Dalam pengujian hipotesis terdapat kriteria pengujian $\mathrm{H}_{0}$ ditolak apabila $\mathrm{t}_{\text {hitung }}>\mathrm{t}_{\text {tabel }}$ dengan $\mathrm{db}=\mathrm{n}-1$ dengan taraf signifikan 5\% dan untuk harga apabila $\mathrm{t}_{\text {hitung }}<\mathrm{t}_{\text {tabel }}$ maka $\mathrm{H}_{\mathrm{o}}$ diterima.

Berdasarkan perhitungan diperoleh t hitung sebesar 22,804 sedangkan t tabel dengan db $=\mathrm{N}-1=41-1=40$, dan taraf signifikan 0,05 sebesar 1,684. Karena $t$ hitung $>t$ tabel yaitu $22,804>1,684$, maka Ho ditolak dan Ha diterima. Artinya model pembelajaran complete sentence berbantu media video berpengaruh terhadap hasil belajar tema pahlawanku.

Model pembelajaran complete sentence dikatakan dapat mencapai ketuntasan belajar siswa kelas IV SD N Tlogomulyo apabila rata-rata yang diperoleh siswa di kelas adalah $80 \%$ dari jumlah siswa mendapat nilai di atas KKM. Berikut ini hasil uji ketuntasan belajar klasikal :

Tabel 3. Uji Ketuntasan

\begin{tabular}{ccccc}
\hline No & Hasil & Tingkat Ketuntasan Minimal & \multicolumn{2}{c}{ Presentase } \\
& & & Tuntas & Tidak Tuntas \\
\hline 1 & Pretest & $80 \%$ & $2561 \%$ & $1639 \%$ \\
2 & Posttest & $80 \%$ & $3893 \%$ & $37 \%$ \\
\hline
\end{tabular}

Sumber : Data Hasil Penelitian (2019)

Ketuntasan belajar siswa secara klasikal mengalami peningkatan. Hal ini dilihat dari hasil pretest dan posttest, dimana hasil pretest lebih baik dibandingkan dengan posttest. Dalam pretest siswa belum diberikan perlakuan sedangkan posttest siswa sudah diberikan perlakuan berupa model pembelajaran complete sentence berbantu media video. Ketuntasan klasikal dikatakan telah tercapai apabila mencapai $80 \%$. Pada hasil perhitungan ketuntasan klasikal siswa mencapai 93\%. Jadi, dapat ditarik kesimpulan bahwa siswa SD N Tlogomulyo sudah mencapai ketuntasan klasikal dan model pembelajaran complete sentence berpengaruh dalam meningkatkan hasil belajar siswa dalam Tema Pahlawanku Subtema Pahlawan Kebanggaanku Pembelajaran 4, 5 dan 6.

Dalam teori belajar Piaget, setiap anak mengembangkan kemampuan berpikirnya menurut tahap yang teratur. Tahapan-tahapan yang terjadi pada anak berbeda satu dengan yang lainnya. Kaitannya dengan permasalahan yang timbul pada kelas IV, perlu diketahui 
bahwa anak-anak termasuk dalam tahap operasional konkrit dimana usianya menginjak kurang lebih antara 7 sampai 11 tahun. Pada tahapan ini, anak bisa berpikir logis dan mampu berpikir secara konkrit sudah menguasai sebuah pelajaran yang penting dengan menggunakan panca indera. Jika dikaitkan dengan penggunaan model pembelajaran complete sentence berbantu media video pada siswa kelas IV, dimana siswa harus mengisi bagian-bagian yang masih kosong, siswa dilatih untuk berpikir berpikir logis dimana harus melengkapi bagian-bagian yang kosong dengan memilih jawaban yang tersedia pada kotak. Dalam hal ini siswa harus bisa melengkapi dengan kata-kata yang sesuai dengan pernyataan. Selain itu, siswa sudah bisa menguasai sebuah pelajaran yang penting dengan menggunakan panca indera, hal ini selaras dengan penggunaan media video yang mana memanfaatkan panca indera yaitu mata. Dengan adanya media video ini diharapkan mampu memudahkan siswa dalam menerima materi dan meningkatkan daya ingat.

Penggunaan model pembelajaran complete sentence terbukti berpengaruh dalam meningkatkan hasil belajar siswa. Hal ini dilihat dari uji t dan uji ketuntasan klasikal siswa. Keberhasilan model pembelajaran complete sentence dalam aspek kognitif, siswa dapat menyebutkan informasi tentang para pahlawan (Patimura, Ki Hajar Dewantara dan Ir. Soekarno) dan menjelaskan sikap yang sesuai dengan sila kelima pancasila yang termuat dalam sebuah paragraf rumpang. Pada aspek afektif terlihat dalam kegiatan kerja kelompok seperti yang tercantum dalam langkah-langkah pembelajaran dan sikap spiritual ketika berdoa sebelum memulai pembelajaran. Sedangkan pada aspek psikomotoriknya dilihat dari keterampilan siswa dalam menceritakan sikap kepahlawanan dengan makna pancasila dan mempresentasikan informasi yang diperoleh. Pada saat pembelajaran memanfaatkan media video dengan tujuan agar dapat membantu siswa dalam memahami materi serta meningkatkan daya ingat sehingga diharapkan dapat meningkatkan hasil belajar siswa. Pada aplikasinya, media video diberikan sebelum pembelajaran dimulai guna menarik perhatian siswa. Hal ini selaras dengan penelitian terdahulu yang berjudul pengaruh model pembelajaran kooperatif tipe complete sentence terhadap hasil belajar IPS pada siswa kelas V SD oleh Ni Made Dwipayanti Agustini dkk yang hasilnya kelas eksperimen lebih tinggi dibandingkan dengan kelas kontrol. Artinya model pembelajaran complete sentence berpengaruh terhadap hasil belajar IPS. Selain itu juga penelitian berjudul penggunaan media audio visual untuk meningkatkan hasil belajar IPS pada siswa kelas IV SD oleh Arya Adittia. Hal tersebut dibuktikan dalam pengujian hipotesis, yang menyatakan bahwa nilai thitung lebih besar dari pada nilai ttabel $(9,427>1,720)$ yang artinya Ho ditolak dan Ha diterima. Perhitungan tersebut menunjukan bahwa terdapat perbedaan pada hasil belajar siswa setelah menggunakan media Audio Visual dalam kegiatan belajar mengajar yang telah dilakukan. Sehingga dapat disimpulkan bahwa pembelajaran dengan menggunakan media Audio Visual dapat meningkatkan hasil belajar siswa.

Berdasarkan uraian di atas dapat disimpulkan bahwa model pembelajaran complete sentence berbantu media video berpengaruh terhadap hasil belajar siswa kelas IV Tema Pahlawanku SD N Tlogomulyo Semarang.

\section{Simpulan dan Saran}

Berdasarkan penelitian yang telah dilakukan, dapat disimpulkan bahwa dengan adanya penggunaan model pembelajaran complete sentence berbantu media video pada pembelajaran tematik khususnya tema Pahlawanku memberikan pengaruh yang signifikan terhadap hasil belajar siswa kelas IV SD N Tlogomulyo. Hal ini dapat dilihat dari hasil pretest dan posttest, dimana pretest sebelum siswa mendapatkan perlakuan dan posttest setelah siswa mendapatkan perlakuan. Dari data yang diperoleh menunjukkan bahwa hasil belajar aspek kognitif lebih tinggi posttestnya dibandingan dengan pretest. Dalam uji t aspek kognitif diperoleh t hitung $>$ t tabel yaitu 22,804 >1,684. Dari uji t yang telah dilakukan, dapat disimpulkan bahwa 
$\mathrm{t}_{\text {hitung }}>\mathrm{t}_{\text {tabel }}$. Berarti $\mathrm{H}_{a}$ diterima. Selain itu, ketuntasan posttest mencapai $93 \%$ sedangkan ketuntasan. Hal ini menunjukkan bahwa model pembelajaran complete sentence berbantu media video berpengaruh terhadap hasil belajar Tema Pahlawanku Subtema Pahlawan Kebanggaanku Pembelajaran ke 4, 5 dan 6 Kelas IV SD N Tlogomulyo.

Berdasarkan penelitian yang telah dilakukan, diharapkan guru dapat menggunakan model pembelajaran complete sentence berbantu media pada pembelajaran tematik di kelas karena model pembelajaran ini dapat meningkatkan hasil belajar siswa. Setiap model pembelajaran memiliki kelebihan dan kekurangan masing-masing, untuk itu sebagai calon pendidik diharapkan dapat meningkatkan kreativitas guna menyelesaikan permasalahan-permasalahan yang ditimbulkan ketika pembelajaran berlangsung.

\section{Daftar Pustaka}

Agustini, Ni Made dkk. 2017. "Pengaruh Model Pembelajaran Kooperatif Tipe Complete Sentence terhadap Hasil Belajar Ips". e-Journal PGSD Universitas Pendidikan Ganesha. $5(2): 3$

Depdiknas. 2013. Perundangan tentang Kurikulum Sistem Pendidikan Nasional 2013. Jakarta: PT Buku Seru

Dimyati dan Mudjiono. 2009. Belajar dan Pembelajaran. Jakarta: PT Rineka Cipta

Farida, Ida. 2017. Evaluasi Pembelajaran Berdasarkan Kurikulum Nasional. Bandung: PT Remaja Rosdakarya

Majid, Abdul. 2014. Pembelajaran Tematik Terpadu . Bandung: PT Remaja Rosdakarya

Masdiana, dkk. "Penerapan Pembelajaran Tematik untuk Meningkatkan Hasil Belajar IPA Materi Pada Lingkungan Siswa Kelas I SD N 018 Letawa Kecamatan Sarjo Kabupaten Mamuju Utara". Jurnal Kreatif Tadulako Online. 3(2)

Shoimin, Aris. 2014. 68 Model Pembelajran Inovatif dalam Kurikulum 2013. Yogyakarta: ArRuzz Media

Sudjana, Nana. 2009. Penilaian Hasil Proses Belajar Mengajar. Bandung: PT Remaja Rosdakarya

Solekhah, Siti. 2014. "Implementasi Pembelajaran Tematik di SD Muhammadiyah Program Khusus Kota Surakarta". Jurnal

Sudjana, Nana. 2016. Penilaian Hasil Proses Belajar Mengajar. Bandung: PT Remaja Rosdakarya

Sugiyono. 2012. Metode Penelitian Pendidikan. Bandung: Alfabeta

Susanto, Ahmad. 2013. Teori Belajar dan Pembelajaran di Sekolah Dasar. Jakarta: Kencana Prenada Media Group. JEAR, Vol. 2, No. 3, Tahun 2018, pp. 240-248 248 JEAR. P-ISSN: 2580-4790 E-ISSN: 2549-3272 
Suyatno. 2009. Menjelajah Pembelajaran Inovatif. Sidoarjo:Masmedia Buana Pustaka.

Trianto. 2009. Mendesain Model Pembelajaran Inovatif-Progresif. Jakarta: Kencana Prenada Media Group.

Wantini, Cucu.2017. "Penerapan Model Pembelajaran Complete Sentence dalam Meningkatkan Keterampilan Menulis Karangan”. Jurnal Upi Mimbar Sekolah Dasar. 4(3): 256-263

Widoyoko, Eko. 2015. Teknik penyusunan Instrumen Penelitian. Yogyakarta: Pustaka Pelajar

Widyanti, Tri.2016. "Pengaruh Model Pembelajaran Complete Sentence Terhadap Kemampuan Menulis Karangan Narasi Pada Siswa Kelas IV SD N Tawang I Kecamatan Wates Kabupaten Kediri Tahun Ajaran 2014/2015". Artikel Skripsi 